\title{
ASSESSMENT OF HEALTH STATUS OF UNDER-SIX-YEAR CHILDREN AT UHTC, SHARIFGANJ AREA OF KMC, KATIHAR, BIHAR
}

\author{
Purnendu Kumar Singh1, Vishal Prasad ${ }^{2}$
}

${ }^{1}$ Associate Professor, Department of Community Medicine, Katihar Medical College, Katihar, Bihar, India.

2Junior Resident, Department of Community Medicine, Katihar Medical College, Katihar, Bihar, India.

\begin{abstract}
BACKGROUND
Under-six-year children comprise approximately $17 \%$ of the total population of the 136 million children born each year in the world. Growing urbanisation is a recent phenomenon in the developing countries. Over the past five decades, India's urban population has increased manifold.

The aim of this study is to assess the health and nutritional status of under-six-year children at UHTC, Sharifganj area of KMC, Katihar, Bihar and with a view to study various socio-economic factors influencing their health status with a view to formulate prophylactic measures.
\end{abstract}

\section{MATERIALS AND METHODS}

An observational study of 1200 children ( 640 boys and 560 girls) was undertaken during August 2017 to March 2018 at urban health training centre Sharifganj area of KMC, Katihar, Bihar. The sample size was calculated on the basis of pilot survey. Children were classified on the basis of weight for age into various categories of malnutrition using IAP classification and NCHS standard.

\section{RESULTS}

Out of 1200 children in the present study, 756 (63\%) were found to be normal. In the age group of $0-<1$ year, 120 infants (84.7\%) were found to be normal category. So, if we exclude the $0-<2$ years children, $484(40.33 \%)$ children were normal and $50.67 \%$ were malnourished (Grade I to Grade IV).

\section{CONCLUSION}

The higher prevalence of malnutrition in the urban area may be due to poor breast-feeding practices, lack of appropriate complementary feeding.

\section{KEYWORDS}

Under 6 Year Children, Breastfeeding, Immunization, Malnutrition, Supplementary Nutrition, Anthropometric Measurement. HOW TO CITE THIS ARTICLE: Singh PK, Prasad V. Assessment of health status of under-six-year children at UHTC, Sharifganj area of KMC, Katihar, Bihar. J. Evolution Med. Dent. Sci. 2018;7(27):3130-3133, DOI: 10.14260/jemds/2018/703

\section{BACKGROUND}

An independent district since 1973, Katihar is primarily an agrarian region. Paddy is the chief commercial crop. However, the district also houses jute and paper mills.

While the total urban population of Katihar is 2, 18 and 246 and total rural population is 21,71 and 287. Also, for every 1000 males, there are 919 females in the region. One of the interesting facts about Katihar is that it has only $23 \%$ of its population below poverty line. With a steadily increasing literacy rate and declining below poverty line mark, Katihar is surely making a mark of its own as one of the 38 districts of Bihar. Children are the assets of nation. In any community, children constitute a priority group. ${ }^{1}$

In sheer numbers $(0-6$ years), children comprise approximately $17 \%$ of the population of the 136 million children born each year in the world, 90 percent are in the $3^{\text {rd }}$ world.

'Financial or Other Competing Interest': None.

Submission 29-05-2018, Peer Review 23-06-2018,

Acceptance 28-06-2018, Published 02-07-2018.

Corresponding Author:

Dr. Purnendu Kumar Singh,

Associate Professor

Department of Community Medicine,

Katihar Medical College, Katihar-854105, Bihar, India.

E-mail: purnendukumars@yahoo.com

DOI: $10.14260 /$ jemds $/ 2018 / 703$

\section{(c) $($ ) $\$$}

Although, the chances of survival of these new-borns has improved by 50 percent in the last 20 years, the first few hours, days and months of their lives are still an obstacle race. From the time of birth, 20 - 30 percent of babies are underweight. That makes them vulnerable to infection and disease. About 40 percent of the total infant mortality occurs in the first month of life. ${ }^{2}$ Then comes the weaning period, when out of four surviving children receives neither the quality nor the quantity of food needed to replace the substances provided by mother's milk. Many low-cost measures are available for saving life of millions of children like immunizations, breastfeeding, birth spacing, growth monitoring, improved weaning and oral rehydration. Attention is focused on these elements of child health care in developing countries.3,4

Growing urbanisation is a recent phenomenon in the developing countries over the past five decades. India's urban population has increased manifold. The proportion of the urban population in India has increased from 10.84\% in 1901 to $25.72 \%$ in 1991 and was $27.8 \%$ in the year 2001.5

In childhood, health is measured in terms of growth of the child. The term "growth" implicates the physical maturation, i.e. increase in the size of body. It is biological phenomenon which influence on many factors like hereditary, nutritional and environmental can be readily observed and easily measured. Physical growth is an important indicator of child health and well-being. It can be affected by various factors 
like genetic condition, environmental, nutritional, socioeconomical and endocrinal influence etc.

According to ICMR (1987), socio-economic status plays a dominant role in growth and physical development of children from different socio-economic classes within the same community differ in their body size at all age. The influence of socio-economic factors is manifested in the nutrition and the entire environment, which the children are compelled to adopt. Children are the human resource and assets of a country. ${ }^{6} \mathrm{~A}$ nation is measured through the health of its children. It is therefore essential that children are allowed to grow in an environment which is suitable to meet their social, emotional and educational needs.

Adolphe Quatlet carried out extensive study on the height and weight of children in different age group and introduced the height and weight of children in different age group and introduced the "Anthropometry."7

Anthropometry provides single most portable universally applicable, inexpensive and non-invasive technique for assessing the size, proportion and composition of human body. It reflects both health and nutritional status and predicts performance, health and survival (WHO, Expert Committee Report). ${ }^{8}$

\section{Aims and Objectives}

To assess the health and nutritional status of under six year children at UHTC, Sharifganj area of KMC, Katihar, Bihar and with a view to study various socio-economic factors influencing their health status with a view to formulate prophylactic measures.

\section{MATERIALS AND METHODS}

The study was carried out by systemic random sampling method and every third house was selected for study. Thus, 760 houses where 1280 children reside were included in the study. The sample size was calculated on the basis of pilot survey results, wherein $32 \%$ under 6 year children were found to have low health profiles in the community surveyed. Rest on this with an acceptable error of $10 \%$ the sample size was obtained to be 850 using the formula.

$$
\mathrm{n}=\frac{4 \mathrm{pq}}{\mathrm{l}^{2}}
$$

Prior written consent was obtained from the parents to be included in this study. Altogether 80 children could not be included either due to refusal of the parent or the absence of the children even after repeated visits.

Thus, total sample size of the present study was 1200 . As this study did not involve any patients or patient's records the Institutional Ethical Committee intimated that ethical clearance was not required.

This community based cross-sectional study was carried out during 2017 - 18. Mother of each child or local guardian was included in the study for personal interview in her own house followed by clinical examination and anthropometric measurement of the child, i.e. weight and height, housing condition, water supply and sanitary practices were looked for the same background characteristics like caste, religion, socio-economic status, demographic status, feeding practices, supplementary nutrition, immunization status, morbidity etc. All this information were recorded on a predesigned and pretested proforma. The study was conducted on 1200 children in a group of 0 - 6 years. Besides other information, anthropometric measurement was done to assess their nutritional and health status.

The most reliable sources of information, viz. the immunisation card of the children and/or MCH card of the mother were checked. Data regarding the source of immunisation was also gathered. In absence of recorded evidence, verbal information from mother of children or father was gathered. Health status of children was studied after weighing the child on Salter's scale to the nearest of 100 grams and using the classification given by IAP with reference to the expected weight for age. The statistical analysis was carried out on SSPS version 17.0.

\section{RESULTS}

Total sample size of the present study was 1200 .

\begin{tabular}{|c|c|c|}
\hline Sex & Number & Percentage \\
\hline Boys & 640 & $53.3 \%$ \\
\hline Girls & 560 & $46.7 \%$ \\
\hline Total & $\mathbf{1 2 0 0}$ & $\mathbf{1 0 0 . 0 0 \%}$ \\
\hline Table I. Showing Sex distribution of Pre-School Children \\
\hline
\end{tabular}

The above table shows the number of pre-school children sex-wise. Boys found to be $53.3 \%$ (640 cases) and girls were found to be $46.7 \%$ (560).

\begin{tabular}{|c|c|c|}
\hline Age Group in Year & Number & Percentage \\
\hline $0-<1$ & 142 & 11.83 \\
\hline $1-<2$ & 228 & 19.00 \\
\hline $2-<3$ & 212 & 17.67 \\
\hline $3-<4$ & 220 & 18.33 \\
\hline $4-<5$ & 190 & 15.83 \\
\hline $5-<6$ & 208 & 17.33 \\
\hline Total & $\mathbf{1 2 0 0}$ & $\mathbf{1 0 0 . 0 0}$ \\
\hline \multicolumn{2}{|c|}{ Table II. Showing Age distribution of Pre-School Children } \\
under 6 years of Age (0 - 6 years) \\
\hline
\end{tabular}

Maximum no. of children were found in $1-<2$ years that is $19.00 \%(228)$ and minimum in $0-<1$ years $(142)$ that is $11.83 \%$.

\begin{tabular}{|c|c|c|}
\hline Religion & Number & Percentage \\
\hline Hindu & 433 & 36.08 \\
\hline Muslim & 767 & 63.92 \\
\hline Total & 1200 & 100.00 \\
\hline \multicolumn{3}{|c|}{$\begin{array}{c}\text { Table III. Showing distribution of Pre-School Children } \\
\text { according to Religion }\end{array}$} \\
\hline
\end{tabular}

Above table shows the data in relation to religion. Muslim children were found to be $767(63.92 \%)$ and Hindu was found to be 433 (36.08\%).

\begin{tabular}{|c|c|c|}
\hline Socio-Economic & Number & Percentage \\
\hline I (upper) & 34 & 4.47 \\
\hline II (upper middle) & 92 & 12.11 \\
\hline III (lower middle) & 104 & 13.68 \\
\hline IV (upper lower) & 190 & 25.00 \\
\hline $\mathrm{V}$ (lower) & 340 & 444.74 \\
\hline Total & 760 & 100.00 \\
\hline
\end{tabular}


Above table shows the distribution of family into five socio-economic groups depending upon education, occupation and income of the parent. Maximum no. of children belonged to socio-economic group $\mathrm{V}$ i.e. 340 $(44.74 \%)$ and minimum in socio-economic group I i.e. 34 (4.47\%).

\begin{tabular}{|c|c|c|c|c|}
\hline \multirow{2}{*}{$\begin{array}{c}\text { Type of } \\
\text { Immunization }\end{array}$} & $\begin{array}{c}\text { Number of Children } \\
\text { Immunised }\end{array}$ & \multicolumn{2}{c|}{$\begin{array}{c}\text { Number of Children } \\
\text { Not Immunised }\end{array}$} \\
\cline { 2 - 5 } & Nos. & $\%$ & Nos. & $\%$ \\
\hline BCG & 960 & $80.00 \%$ & 233 & $19.42 \%$ \\
\hline Oral Polio & 912 & $76.00 \%$ & 287 & $23.92 \%$ \\
\hline Pentavalent & 888 & $74.00 \%$ & 312 & $26.00 \%$ \\
\hline Measles & 156 & $13.00 \%$ & 1045 & $87.08 \%$ \\
\hline Table V. Showing Immunization Coverage of Children by at \\
least one of the Immunizing Agent in relation to Sex \\
\hline
\end{tabular}

Above table is self-explanatory.

\begin{tabular}{|c|c|c|}
\hline Nutritional Status & Number & Percentage \\
\hline Above $80 \%$ (Normal) & 756 & $63.0 \%$ \\
\hline 71-80\% (Grade I) & 214 & $17.83 \%$ \\
\hline 61-70\% (Grade II) & 181 & $15.08 \%$ \\
\hline 51-60\% (Grade III) & 44 & $3.67 \%$ \\
\hline$<50 \%$ (Grade IV) & 5 & $0.42 \%$ \\
\hline Total & 1200 & $100.00 \%$ \\
\hline
\end{tabular}

The above table shows that present study, the percentage of children in Grade I, II and III malnutrition were 17.83\%, $15.08 \%$ and $3.67 \%$. The percentage of normal children was $63.0 \%$ according to weight for age criteria.

\begin{tabular}{|c|c|c|c|c|c|c|c|c|c|c|}
\hline \multicolumn{5}{|c|}{ Male } & \multirow[t]{2}{*}{$\begin{array}{c}\text { Age Group } \\
\text { in Years }\end{array}$} & \multicolumn{5}{|c|}{ Female } \\
\hline $\begin{array}{l}\text { No. of } \\
\text { Boys }\end{array}$ & Range & $\begin{array}{c}\text { Mean } \\
\text { Weight }\end{array}$ & \pm SD & $\pm \mathrm{SE}$ & & $\begin{array}{l}\text { No. of } \\
\text { Girls }\end{array}$ & Range & $\begin{array}{c}\text { Mean } \\
\text { Weight }\end{array}$ & \pm SD & $\pm \mathrm{SE}$ \\
\hline 108 & $4.6-12.2$ & 7.92 & 2.27 & 0.24 & $0-<1$ & 96 & $7.8-13.8$ & 10.72 & 1.93 & 0.22 \\
\hline 110 & $4.8-12.5$ & 7.99 & 2.30 & 0.28 & $1-<2$ & 92 & $5.0-11.0$ & 7.46 & 1.87 & 0.24 \\
\hline 114 & $6.0-11.5$ & 9.50 & 0.97 & 0.12 & $2-<3$ & 98 & $6.0-12.0$ & 9.07 & 1.32 & 0.18 \\
\hline 122 & $8.0-13.0$ & 11.26 & 1047 & 0.17 & $3-<4$ & 94 & $7.0-13.0$ & 9.96 & 1.47 & 0.20 \\
\hline 92 & $10.0-19.0$ & 14.75 & 2.85 & 0.39 & $4-<5$ & 82 & $8.0-14.5$ & 11.93 & 1.83 & 0.26 \\
\hline 94 & $9.0-20.0$ & 14.92 & 2.92 & 0.37 & $5-<6$ & 78 & $8.0-18.0$ & 13.58 & 2.82 & 0.37 \\
\hline
\end{tabular}

Above table shows that the mean weight increases with age in both sexes. The total increase in mean weight between 0 and 6 years in boys was found to be $6.93 \mathrm{~kg}$ and in girls was $6.12 \mathrm{~kg}$. In boys the mean weight was observed to be $7.99 \mathrm{~kg}$ for the age group $1-<2$ and $14.92 \mathrm{~kg}$ for the age group $5-<6$ years, whereas in the case of girls' mean weight for the age group $1-<2$ was obtained to be $7.46 \mathrm{~kg}$ and for the age group $5-<6$ was $13.58 \mathrm{~kg}$. The overall mean weight for the age group 1 to 6 years obtained as 11.52 and $10.35 \mathrm{~kg}$ for boys and girls respectively. Overall, mean weight for all children under study was found to be $10.97 \mathrm{~kg}$.

\begin{tabular}{|c|c|c|c|c|c|c|c|c|c|c|}
\hline \multicolumn{5}{|c|}{ Male } & \multirow{2}{*}{$\begin{array}{c}\text { Age Group } \\
\text { in Years } \\
\end{array}$} & \multicolumn{5}{|c|}{ Female } \\
\hline $\begin{array}{l}\text { No. of } \\
\text { Boys }\end{array}$ & Range & $\begin{array}{c}\text { Mean } \\
\text { MUAC } \\
(\mathrm{cm})\end{array}$ & \pm SD & $\pm \mathrm{SE}$ & & $\begin{array}{l}\text { No. of } \\
\text { Girls }\end{array}$ & Range & $\begin{array}{c}\text { Mean } \\
\text { MUAC } \\
(\mathrm{cm})\end{array}$ & \pm SD & $\pm \mathrm{SE}$ \\
\hline 108 & $7.3-11.0$ & 10.7 & 1.26 & 0.14 & $0-<1$ & 96 & $6.9-11.2$ & 10.11 & 1.17 & 0.13 \\
\hline 110 & $8.2-12.5$ & 11.02 & 1.35 & 0.17 & $1-<2$ & 92 & $7.5-12.5$ & 10.82 & 1.29 & 0.16 \\
\hline 114 & $10.3-13.5$ & 11.41 & 1.03 & 0.12 & $2-<3$ & 98 & $9.7-14.3$ & 11.03 & 1.61 & 0.22 \\
\hline 122 & $11.0-14.7$ & 12.50 & 0.96 & 0.11 & $3-<4$ & 94 & $10.3-14.4$ & 12.12 & 1.15 & 0.16 \\
\hline 92 & $12.1-16.2$ & 13.80 & 1.13 & 0.15 & $4-<5$ & 82 & 11.4-15.2 & 13.25 & 1.28 & 0.18 \\
\hline 94 & $12.3-16.5$ & 14.63 & 1.37 & 0.17 & $5-<6$ & 78 & $11.2-17.1$ & 14.01 & 1.09 & 0.14 \\
\hline
\end{tabular}

The above table shows that mean upper mid arm circumference (in $\mathrm{cm}$ ) increases steadily with the increase in age in both sexes. In boys MUA circumference were obtained to be $11.02 \mathrm{~cm}$ in the age group $1-<2$ and $14.63 \mathrm{~cm}$ in the age group $5-<6$. Overall, mean mid arm circumference for all age were found to be $12.60 \mathrm{~cm}$ in boys and $12.22 \mathrm{~cm}$ in girls indicating that boys are having larger MUAC than that of girls.

\section{DISCUSSION}

The present work "Assessment of Health Status of Under Six Year Children at UHTC, Sharifganj Area of KMC, Katihar, Bihar," was conducted in urban population of Katihar, which is $8 \mathrm{~km}$ from Katihar Medical College.

It gives a very vulnerable and important result about socio-economic status, immunization status, nutritional status and anthropometric measurement.
Nutritional and Health Status of Community can be assessed by following Methods-

1. Clinical examination.

2. Laboratory and biochemical examination.

3. Anthropometric measurement.

Anthropometry provides the single most portable universally applicable, inexpensive and non-invasive technique for assessing the size proportion, composition of human body. It reflects both health and nutritional status and predicts performance, health and survival. ${ }^{9}$ 
Nutritional anthropometry is considered to be the best method for assessment of health status. It is considered with the measurement of variation in physical dimension and gross composition of the human body at different age levels. It is easy to perform and require only single apparatus. . $^{10,11}$

Malnutrition is much more prevalent in developing countries. We come across very few cases of severe malnutrition. For it exhibits "Iceberg phenomenon," any case of overt malnutrition. We represent only the tip of the problem. The main bulk is submerged undetected in the community. By using anthropometric measurement, one can detect the subclinical malnutrition very easily. ${ }^{12}$

Assessment of health status of individual consequently for health assessment purpose, anthropometry is most useful parameter for assessing the nutritional status of children, particularly in developing countries. ${ }^{13}$

Jelliffe DB 1966, Bhandari and Jain 1972 also observed that the malnutrition especially in developing countries like India where resources of good food are limited.11

ICMR (1972) reports that the weight, height and chest circumference complements are another and give information on nutritional status which is less in protein caloric malnutrition. ${ }^{14}$

OP Ghai (1977) emphasised the importance of anthropometry and detecting the malnutrition. Similar view also expressed by Dutta Banik et al (1973), Raghwan et al (1973) and Gupta (1977).15

Out of 1200 children in the present study, 756 (63\%) were found to be normal. The children were classified on the basis of nutrition to indicate weight for age, into various categories of malnutrition using IAP classification and NCHS standard. In the age group of $0-<1$ year, 120 infants (84.7\%) were found to be normal category. So, if we exclude the $0-<2$ years children as $484(40.33 \%)$, children were normal and $50.67 \%$ were malnourished (Grade I to Grade IV). Table VIII showed that maximum cases of malnutrition are in the age group of $5-<6$ years. 56 (41.35\%) Grade I, 40 (19.23\%) Grade II ( 40 cases, i.e. $21.05 \%$ in the age group $4-<5$ years), 10 cases of $4.8 \%$ for Grade III and 2 cases (0.96\%) for Grade IV ( 2 cases i.e. $1.33 \%$ in the age group of $4-<5$ years). In Grade I malnutrition, minimum cases were recorded in the age group $1-<2$ years (15) and $2-<3$ years (20). In Grade II also minimum cases ( 4 cases $2.82 \%$ ) were seen in the age group of $0-<1$ year, so also in Grade III where only 3 cases $(2.11 \%)$ were in $0-<1$ year and $1-<2$ years.

Thus, these studies are comparable and present a dismal picture of the health status of children of families residing in UHTC, Sharifganj area of Katihar Medical College, Katihar, Bihar.

\section{CONCLUSION}

The higher prevalence of malnutrition in the urban area may be due to poor breast-feeding practices, lack of appropriate complementary feeding, prevalent in society, discarding of colostrum, delayed initiation of breast feeding, lack of education and higher number of children in low socioeconomic group is the prime reason for poor health profile of children in this region.

\section{REFERENCES}

[1] Dwivedi SN, Banerjee N, Yadav OP. Malnutrition among children in an urban slum and its associations. Indian J Maternal and Child Health 1992;3(3):79-81.

[2] International Institute for Population Sciences (IIPS) National Family Health Survey (NFHS-3), 2005-06: India. Mumbai: IIPS, 2007.

[3] Ruel MT, Menon P, Habicht JP, et al. Age based preventive targeting of food assistance and behaviour change and communication for reduction of childhood undernutrition in Haiti: a cluster randomised trial. Lancet 2008;371(9612):588-95.

[4] Anderson MA. Comparison of anthropometric measures of nutritional status in preschool children in five developing countries. Am J Clinical Nutri 1979;32(11):2339-45.

[5] Asharf M, Gaash B, Bhat NA, et al. Efficiency of weight/height ratio in detection of protein energy malnutrition in Gujjar, Bakarwal and Pahari preschool children. Indian Journal of Maternal Child Health 1997;8(2):58-9.

[6] Busi BR, Leela SM, Babu RADW, et al. Growth pattern among pre-school children in urban slums of Visakhapatnam. The Ind J Nutr Dietet 1991;28:188-93.

[7] Ramnath T, Vijayaraghavan K, Rao NP. Nutritional anthropometry - validity of cut-off points. J Trop Pediatr 1993;39(4):200-4.

[8] WHO: Measuring change in nutritional status. World Health Organisation, Geneva (1983 Calliara M profile of an Indian child). Social Welfare 1989;36:33-4.

[9] Boerma JT, Sommerfelt AE, Bicego GT. Child anthropometry in cross- sectional surveys in developing countries: an assessment of the survivor bias. Am J Epidemiology 1992;135(4):438-49.

[10] Indian Council of Medical Research, Nutritive value of Indian foods. New Delhi, 1981.

[11] Jelliffe DB. The assessment of the nutritional status of the community. WHO monograph series, no. 53. Geneva: WHO 1966.

[12] Ghosh S. The feeding and care of infants and young children. New Delhi: Voluntary Health Association of India, 1977.

[13] Indian Council of Medical Research. Recommended dietary intakes for Indians. New Delhi, 1981;98:53942.

[14] I.C.M.R: Growth \& Dev of Ind Infant \& Children. Tech. Ref. Ser No. 18. 1972.

[15] International Institute for Population Sciences and ORC Macro. National Family Health Survey (NFHS-2) 1998-99. India. Mumbai: IIPS, 2001:(5). 